\title{
Determinants of Smallholder Farmers' Saving: The Case of Omo Microfinance Institution in Gimbo District of Kaffa Zone, Southern Ethiopia
}

\author{
Ejigu Mulatu \\ Southern Agricultural Research Institute, Bonga Agricultural Research Center, Bonga, Ethiopia \\ Email address: \\ ejigum61@gmail.com \\ To cite this article: \\ Ejigu Mulatu. Determinants of Smallholder Farmers' Saving: The Case of Omo Microfinance Institution in Gimbo District of Kaffa Zone, \\ Southern Ethiopia. International Journal of Accounting, Finance and Risk Management. Vol. 5, No. 2, 2020, pp. 93-100. \\ doi: 10.11648/j.ijafrm.20200502.14
}

Received: September 4, 2019; Accepted: October 26, 2019; Published: April 17, 2020

\begin{abstract}
Despite the importance of saving to both savers and financial institution, different household and institutions related factors separated a lot of farmers from saving in Microfinance institutions. This study was conducted with specific objectives: to identify factors affecting farmers' saving in microfinance institution and to assess challenges and opportunities in microfinance service provision in the Gimbo district of Kaffa zone, Southern Ethiopia. The study was based on the data collected from 200 sample households selected through two-stage sampling technique. Both descriptive statistics and econometric model were used to analyze the data. A Tobit model was used to assess the determinants of households' saving. Econometric model result showed that education level, land size, farm income, household expenditure, distance from service provision center, and perception on interest rate were found to be significant in influencing the households' saving in Omo micro-finance. Low loan recovery performance, low saving mobilization, lack of office facilities, lack of awareness on services and lack of coordination with other government sectors were major challenges in microfinance service provision in the district. The result suggests the need of microfinance institution and concerned government bodies playing role regarding improving saving culture of households through financial literacy, modernization of working procedures in saving service provision, and reviewing the saving interest rate for encouraging farmers to save.
\end{abstract}

Keywords: Microfinance, Rural Households, Saving, Tobit Model

\section{Introduction}

In Ethiopia with population of 96.5 million, from which, 79.3 million living in rural area being employed in agriculture [1]. Financial institutions help farmers to save their cash reserves efficiently to better protect themselves from shocks before they occur, and increase liquid assets to smooth consumption against income shocks [2]. The formal financial sector in Ethiopia have inadequate outreach of the rural areas as reason of the risks and uncertainty related to smallholder farmers' income, lack of collateral and development of the rural markets and low development of infrastructure [3].

Farmers living at subsistence levels often just want a safe place to save and manage their risk and want to make withdrawal at the time they face shortage from the benefit of their saves. To improve agricultural productivity and poverty reduction from a rural household and a nation as a whole, a powerful tool is provision of microfinance services to the poor in a sustainable way. That is why microfinance institutions (MFIs) are basically established to serve the poors who lack access to formal financial services [4].

Although consecutive reforms and efforts were made by the MFIs and conducive regulatory framework and substantial government support given for the institution to sustain the service, participation of smallholder farmers in the service is low and affected by various factors. Some of these factors are different socioeconomic factors; a lack of innovative demand-driven financial services and lack of sustainable institutions that can provide for the huge unmet demand of smallholder farmers [5]. For instance, [6] study, in Oromia region showed that the average savings of the 
sampled clientele during their six years stay with the microfinance institution was about 1762 birr.

It is believed that satisfying client demand for safe and liquid saving instrument is just as important as satisfying their demand for credit. This is related with the importance of saving being source of funds for lenders and increased source of further investment for savers [7]. Despite the importance of saving to both savers and the institution, some microfinance programs were not effective in mobilizing savings and showed little interest in doing so. Due to this reason, still there is little attention given to saving and that is why saving of farm households is very low [8].

On the other hand, different household and institutions related factors separated a lot of farmers from saving in MFIs. These factors include low interest rate of saving, lack of incentives to savers and high inflation rates, attitude of the societies towards consumption than saving and demographic factors age, gender, education level, income level, and number of dependents are factors affecting saving behavior of households. Mobilizing savings, particularly in rural areas, requires careful planning and product design as winning the trust of poor clients and convincing them to put their sensitive money into the custody of MFIs. However, little attention was given by microfinance institutions in doing so [9].

Reports showed that, total of 33 MFIs in the country have been providing saving and credit service for poor households, who were neglected by banks. These MFIs mobilized total saving of birr 14.2 billion and their total asset increased to be 29 billion [9]. Among these MFIs, Omo Microfinance Institution (OMFI) is the one which has been working in the southern Nations, Nationalities and Peoples Regional State (SNNPRS) in general and in the Gimbo district in particular. The institution is one of five largest MFIs in the country; Amhara, Dedebit, Oromiya, Omo and Addis Credit and Savings institutions (ibid). According to data obtained from Omo microfinance institution a total of 7, 613,130 birrs of saving was mobilized from 779 depositors in the year 2015/16 in Gimbo district; showing considerable contribution of in serving low income segments of the society in the district [10].

In the case of Omo Microfinance Institute (OMFIs), saving $20 \%$ of the requested loan is needed but, the majority were not voluntary depositors, showing the institution is losing the advantages that support improving the performance of the institutions [11]. The reasons for low saving was mainly related with different household related characteristics and microfinance attributes [12]. As the importance of household saving in a national saving, in the country, the study related to rural households' saving also has great importance. This is because the great majority of the population are living in the rural community of the country. With regards to this, no study has been conducted in south western Ethiopia; particularly in Gimbo district where this study was conducted. Hence, this study was conducted to identify different factors affecting farmers' saving in Omo Micro-Finance Institution to take immediate actions on the bottlenecks and improving the prevailing weaknesses in service provision. Therefore, the study was conducted with specific objectives to identify factors affecting farmers saving in Omo microfinance institution, to assess saving behavior of farmers in Omo microfinance institution, and to assess challenges and opportunities in microfinance service provision in the district.

\section{Research Methodology}

\subsection{Description of the Study Area}

The study was conducted in Gimbo district of Kaffa Zone, Southern Ethiopia; which is located $18 \mathrm{~km}$ far from Bonga, $722 \mathrm{~km}$ from regional town, Hawassa, and $442 \mathrm{~km}$ from Addis Ababa. The total population of the district is 117,588 and from which 58,559 were men and 50,059 were women. Most of these population were rural dwellers and only 13,438 were urban inhabitants. The total number of households of the district is 12,311; and from these 10,942 are men and 1369 are women headed households [13].

The district is composed of 35 kebeles with total area coverage of 88,129 hectares. From this, 1064 hectare is arable land, 28,240 hectares is forest cover, 30,531 hectares is covered by permanent crops, and 10,177 hectares is covered by annual crops, grazing land covers 855 hectares, wetlands cover 7257 hectares, and plantation forest (private) covers 1,259 hectares. Agriculture is the main source of income for majority of rural households. Maize, pepper, coffee, finger millet, sorghum, rice, tea, and common bean are major crops cultivated in the district [ibid].

The commercial bank of Ethiopia has one branch in the district and it is the only formal financial institution providing financial service in the district. In addition to this, Omo microfinance institution was providing the financial service in the district with main objective of saving and credit services provision for poor households living in urban and rural areas [13]. Omo Microfinance Institution was established in October, 1997 following the proclamation №. 40/1996 and legally registered by the National Bank of Ethiopia in the SNNPRS aiming mainly to bridge the gap of formal institutions to meet the need of small-scale borrowers in income generation schemes [14]. OMFI is delivering two types of saving service. These are compulsory and voluntary saving. The compulsory saving is mainly related to the credit service that has been delivered by the institution and each credit client is expected to save in this scheme. However, voluntary saving has been made based of the free choice and willingness of the individuals or organizations $[10,15]$.

\subsection{Sampling Technique and Sample Size Determination}

To select sample respondents, two-stage sampling technique was employed. In the first stage four Kebeles were randomly selected from 31 rural kebeles in the district. In the second stage, 200 representative sample household heads were randomly selected. Formula from [16] was used to determine appropriate sample size as follows: 


$$
\mathrm{n}=\frac{N}{1+N(e)^{2}}
$$

where, $\mathrm{n}$ is sample size; $\mathrm{N}$ is target population, and e is level of precision. Based on this formula, by assuming level of precision $7 \%$, and given number of total rural households in the district, 200 sample size was determined.

\subsection{Data Sources and Methods of Data Collection}

In this study, both primary and secondary data sources were used to gather necessary data regarding smallholder farmers' saving in OMFI. The primary data was collected from the selected sample of 200 smallholder farmers from four kebeles of the district. In addition, key informants' interview and focus group discussion was conducted with selected participants who have experience and knowledge on OMFI service provision. Based on their involvement in the service provision of OMFI, 12 experts were selected purposively (four experts from kebele OMFI experts, four experts from Gimbo district sub branch office of OMFI and four key informants from sample kebele administrative chairman). Furthermore, secondary data were also obtained from published and unpublished documents of individuals, different organizations including Gimbo district office of agriculture and rural development and district sub-branch offices of OMFI.

\subsection{Methods of Data Analysis}

The sample respondents' demographic and socioeconomic conditions as well as saving practices was analyzed using descriptive statistics like mean, standard deviations, frequency and percentage. Data on challenges and opportunities of microfinance service provision was analyzed in qualitative approach. Finally, determinants of households' saving in OMFI was analyzed by using Tobit model.

\subsection{Specification of Tobit Model}

Tobit Model used to analyze determinants of households' saving in OMFIs. The model is chosen because the continuous variable (amounts of saving) tend to be censored at the lower limit of zero for those who have no saving account in the institution [17]. In this study the model was selected because it was assumed to be efficient as it allows using all necessary explanatory variables in the model given fewer number of sample farmers with positive amount of saving. The model is specified as follows

$$
\begin{aligned}
& Y_{i}^{*}=X_{i} \beta+\mu_{i} \\
& y_{i}^{*}=\begin{array}{c}
s^{*}=\beta X_{i}+\mu i \text { if } s *>0 \\
0 \text { if } s * \leq 0
\end{array}
\end{aligned}
$$

Where $\mathrm{S}$ : is the observed amount of household savings in micro finance institution, $S^{*}$ : is the latent variable that is not observed $\beta$ : is a vector of parameters to be estimated, $\mathrm{X}_{\mathrm{i}}$ : is vector of explanatory variables affecting participation in saving $\mu i$ : is residuals, which are assumed to be independently and normally distributed with zero mean and constant variance.

The model parameters are estimated by maximizing Tobit likelihood functions of the following form [17].

$$
L=\prod_{s^{*}}>0 \frac{1}{\sigma}\left(\frac{s i *-\beta i X i}{\sigma}\right) \prod_{s *} \leq 0 F\left(\frac{-\beta i X i}{\sigma}\right)
$$

Where $\mathrm{f}$ is density probability function and $\mathrm{F}$ is cumulative probability functions of $\mathrm{S}^{*}, \Pi\left(\mathrm{S}^{*} \leq 0\right)$ stands for the product over i for which $\mathrm{S}^{*} \leq 0$ and $S *>0$ is the product over those $\mathrm{i}$ for which $\mathrm{S}^{*}>0$.

The marginal effect of an explanatory variable on the expected value of dependent variable is

$$
\frac{\partial e(s *)}{\partial X i}=f(z) \beta i \text { where } z=\frac{\beta X i}{\sigma}
$$

change in intensity of dependent variable with respect to change in an explanatory variable among saving category is

$$
\frac{\partial E\left(\frac{S i}{S i *}>0\right)}{\partial X i}=\beta i\left[1-z \frac{f(S)}{F(z)}-\left(\frac{f(S)}{F(z)}\right)^{2}\right]
$$

$F(Z)$ is cumulative normal distribution of $Z, f(z)$ is the value of the derivative of the normal curve at a given point (i.e. unit normal density), $\mathrm{Z}$ is the zero-score area under the normal curve, $\beta$ is a vector of Tobit maximum likelihood estimate and $\sigma$ is the standard deviation of the error term.

Table 1. Summary of definitions of variables and working hypotheses.

\begin{tabular}{lll}
\hline Variables & Type & Expected Relation \\
\hline $\begin{array}{l}\text { Dependent } \\
\text { Households Saving (birr) }\end{array}$ & Continuous & \\
$\begin{array}{l}\text { Independents } \\
\text { Age of the household head }\end{array}$ & Continuous & + - \\
$\begin{array}{l}\text { Education level of household } \\
\text { head }\end{array}$ & Continuous & + \\
$\begin{array}{l}\text { Sex of household head } \\
\text { Dependency ratio }\end{array}$ & Dummy & + \\
$\begin{array}{l}\text { Participation in off farm income } \\
\text { Farm income of household in birr }\end{array}$ & $\begin{array}{l}\text { Dummy } \\
\text { Continuous }\end{array}$ & + \\
$\begin{array}{l}\text { Households expenditure in birr } \\
\text { Livestock ownership in TLU }\end{array}$ & $\begin{array}{l}\text { Continuous } \\
\text { Land size of household in ha }\end{array}$ & - \\
$\begin{array}{l}\text { Continuous } \\
\text { Distance to OMFI service }\end{array}$ & + \\
provision (Km) & Continuous & + \\
$\begin{array}{l}\text { Perception on interest rate } \\
\text { Frequency of extension contact }\end{array}$ & Continuous & - \\
\hline
\end{tabular}

\section{Results and Discussion}

\section{Sample Households' Characteristics}

The sample was composed of both male and femaleheaded households. From the total sample households, 86.5 percent were male headed households and 13.5 percent were female headed households. The mean education level of sample households was 1.84 , showing lower education level of households. Small and fragmented land ownership of households seen in the district with maximum of 5.25 hectares owned by a farmer and mean of 2.17 hectares. This might be one of factors for lower saving habit of farm households in the district. Farmers on average earned annual farm income of 16,186 birr with minimum of 1,200 and 
maximum of 45,950 birrs. On the other side, average households' expenditure was 13850 birrs. The experience of farm households in participating in off/non-farm activities was weak. Households traveled $7.62 \mathrm{~km}$ on average to reach service provision center of OMFI (Table 2).

Table 2. Sample households characteristics.

\begin{tabular}{lllll}
\hline Variable & Mean & Minimum & Maximum & Std. Dev. \\
\hline Sex & 0.86 & 0 & 1 & 0.342 \\
Age & 45.63 & 25 & 71 & 10.122 \\
Education level & 1.845 & 0 & 12 & 2.391 \\
Total land size & 2.178 & 0 & 5.25 & 0.948 \\
Livestock (TLU) & 3.596 & 1.289 & 9.21 & 1.287 \\
$\begin{array}{l}\text { Households } \\
\text { expenditure }\end{array}$ & 13850.64 & 1277 & 63350 & 7863.07 \\
Farm income & 16186.41 & 1200 & 45950 & 7977.173 \\
$\begin{array}{l}\text { Distance to OMFs } \\
\text { Extension contact }\end{array}$ & 7.622 & 4 & 24.5 & 4.047 \\
$\begin{array}{l}\text { Perception on } \\
\text { interest rate }\end{array}$ & 11.265 & 0 & 26 & 6.427 \\
$\begin{array}{l}\text { Participation in off } \\
\text { farm income }\end{array}$ & 0.07 & 0 & 1 & 0.255 \\
\hline
\end{tabular}

Source: Household survey data (2018).

\section{Households' participation in saving}

From the total of 200 sample respondents, 65 (32.5\%) participated in saving service of Omo microfinance institution. Despite the fact that saving would contribute to the depositors and OMFI, weak saving behavior of households was seen in the district. As saving is requirement for loan use from OMFI, most of savers were credit user households. There are two types of saving accounts that households used in OMFI. The first one is voluntary saving for credit users and non-users (OMFI call it non-client voluntary saving). In this account a client starts saving before credit application and continues during at the time that the client stays with the institution. Since it includes both credit users and non-users, the number of savers and also amount of money deposited in this account was larger than the other one. All respondents who were savers (32.5\%) owned this account and the average amount of money a household saved on it was 2,460 birrs with minimum of 200 and maximum of 17500 birrs (Table 3 ).

The other saving account type is, credit user voluntary and compulsory saving. Despite it includes voluntary saving, clients consider it as solely compulsory saving. This type of saving is only for credit users. Fixed amount of money in compulsory saving with restriction on withdrawal until the full loan is repaid and voluntary saving which starts from the fixed initial amount up to any larger amount the saver can do being saved by monthly together. The average amount saved in this account was 177.69 birr and $26 \%$ of respondents owned this account. In line with the prior findings, there was low saving mobilization in the district, showing the remaining actions to the institution to attract more saver households in effective and sustainable manner.
Table 3. Households' saving in OMFI (2016/17).

\begin{tabular}{lllll}
\hline Saving account & Mean & Mi & Max & St. deviation \\
\hline $\begin{array}{l}\text { Non-client voluntary saving } \\
(\mathrm{N}=65)\end{array}$ & $2,460.08$ & 200 & $17,500.00$ & $3,062.04$ \\
$\begin{array}{l}\text { Credit user compulsory and } \\
\text { voluntary saving ( } \mathrm{n}=52)\end{array}$ & 177.69 & 60 & 240 & 49.73 \\
\begin{tabular}{l} 
Total saving (Birr) \\
\hline
\end{tabular} & $2,602.23$ & 250 & $17,700.00$ & $3,062.193$ \\
\hline
\end{tabular}

Source: Household survey data (2018).

Most of savers in Omo microfinance institution were credit users. Since prior saving of $20 \%$ of loan requested is necessary condition for credit application, households who need credit should have saving. Related with this precondition, from sample respondents, $72.3 \%$ of saving account owners saved in purpose of using credit. About $23.1 \%$ of savers did it in motive of both credit use and money accumulation for future investment. These savers have deposit higher than $20 \%$ of loan they need or already borrowed, as they have motive of money accumulation in addition to credit use. Fewer households $(4.63 \%)$ saved in purpose of money accumulation without credit use intention (Table 4). In comparison, these savers have higher amount of deposit.

Table 4. Client households' motives of saving in OMFIs.

\begin{tabular}{lll}
\hline Why do you save in OMFI? & Frequency & Percent \\
\hline For using credit service purpose & 47 & 72.30 \\
Both credit and money accumulation purpose & 15 & 23.07 \\
Money accumulation purpose & 3 & 4.63 \\
Total & 65 & 100.00 \\
\hline
\end{tabular}

Source: Household survey data (2018).

One of major objectives of microfinance institution is helping farmers to save their cash reserves efficiently to better protect themselves from shocks before they occur, and increase liquid assets to smooth consumption against income shocks [2]. However, low interest rate for saving; inconvenient withdrawal system and complicated working procedure lacking modernized instruments were some of problems that respondents mentioned as institution related reason for low saving habit in the district. From non-saver households, 61.5 percent didn't save in OMFI due to low interest rate of the institution. About 23 percent didn't own saving account due to the reason they didn't like working procedure of the institution, while 4.4 percent mentioned that even they didn't trust OMMFI to save there. Nearly 11 percent didn't save because they had no surplus money to save (Table 5). Participants in focus group discussion also mainly mentioned the problem of low interest rate and working procedures of the institution for low saving of households in OMFI.

Table 5. Reasons for non-saver households in OMFI.

\begin{tabular}{lll}
\hline Why did not save in OMFI? & Frequency & Percent \\
\hline Low interest rate of OMFI & 83 & 61.5 \\
Do not like working procedure of OMFI & 31 & 23.0 \\
No surplus money to save & 15 & 11.1 \\
Do not trust the institution & 6 & 4.4 \\
Total & 135 & 100.0 \\
\hline
\end{tabular}

Source: own survey result (2018). 


\section{Determinants of households' saving}

Education: education level of a household head was significant at $5 \%$ level of significance in positive relation to households' saving. If household head has one year more education, they would have 158.90 birrs more saving. This is because, being literate may put households in a relatively better position to gather, understand and realize information on microfinance services and the working procedures of OMFI. Furthermore, education helps making rational decisions about saving and increases farm management skills of farmers that have positive impact on their farm output and income which in turn would increase their saving. This is consistent with $[18,12,19]$ who showed positive relation between households' saving and education level.

Land size: the variable affected households' saving positively and significant at $1 \%$ level of significance. The model output showed that if household heads have one hectare more land size, they would have 668.84 birrs more saving. Given other factors of production, larger land size increases farm production as compared to smaller land size. Consequently, farm households who own larger land size produce more output which results in higher farm income and saving. In addition, households with larger land size need more finance to operate on their farm. Since saving is one of preconditions to obtain credit, those households who need credit save in microfinance institution in in order to get loan and also continue saving during loan repayment time. The finding is consistent with $[20,19]$ who showed positive relation between household saving and land size owned.

Farm income: Farm income affected households saving positively and significant at $1 \%$ significance level. If household heads earn one birr more farm income, they would have 0.08 birrs additional saving. From the economic theory, the relation between aggregate consumption or aggregate savings and aggregate income, Keynes took it for granted that current consumption expenditure is a highly dependable and stable function of current income [21]. Having no surplus money beyond farm and household expenditure was one of major reasons for low saving practice in formal financial system among farm households in Ethiopia [15]. The finding is consistent with $[12,22]$ who showed positive and significant relation between saving and income.

Household expenditure: as prior expectation, the model output showed negative relation between households saving and households' expenditure and it was significant at 5\% level of significance. The marginal effect from the model output showed that if household heads have one birr more household expenditure, their saving would be decreased by 0.04 birr.

Distance from MFIs: distance from households' residence to microfinance service provision center is significant at $10 \%$ level of significance in negative relation with saving. If household heads live one kilometer more distance from microfinance institution, they would have 170 birrs less saving. This is because households' residence far away from the institution coupled with the institutions' inconvenient saving procedure and lengthened loan disbursement process discouraged some farmers to save more in OMFI. Similar findings by [22-23] identified distance remains a major barrier to formal financial saving and other markets in rural areas.

Perception about interest rate: perception on saving interest rate was related with households saving in microfinance institution and significant at 5\% level of significance. The marginal effect from the model output revealed that, if household heads perceive that saving interest rate of microfinance is fair, they would have 1159 birrs more saving. Most of the respondents and participants in the focus group discussion also mentioned that saving interest rate was not attractive and it was one of major problem for lower saving of households in the microfinance institution. The finding is consistent with [24].

Table 6. Determinants of households' saving (Tobit model result).

\begin{tabular}{llll}
\hline Variables & Coefficient & $\begin{array}{l}\text { Standard } \\
\text { error }\end{array}$ & $\begin{array}{l}\text { Marginal } \\
\text { effect }\end{array}$ \\
\hline Age & -23.067 & 22.025 & -18.666 \\
Sex & 756.157 & 955.982 & 611.897 \\
Education level & $196.365^{* *}$ & 80.942 & 158.903 \\
Dependency ratio & -1195.62 & 927.626 & -967.524 \\
Land size & $826.524 * * *$ & 242.110 & 668.840 \\
Livestock owned & -175.075 & 272.082 & -141.674 \\
Off/non-farm income & 480.835 & 498.010 & 389.101 \\
Farm income of household & $0.109 * * *$ & 0.035 & 0.088 \\
Expenditure & $-0.046 * *$ & 0.026 & -0.037 \\
Distance & $-210.221 *$ & 110.616 & -170.115 \\
Extension contact & -21.486 & 30.965 & -17.387 \\
Perception on interest rate & $1432.204^{* *}$ & 552.920 & 1158.968 \\
cons & 3574.662 & 2236.673 & \\
\hline /sigma & 1583.697 & 138.879 & \\
Log likelihood=-571.11964 & & LR chi ${ }^{2}(12)=84.71$ \\
Number of observations $=65$ & & Prob $>$ chi $^{2}=0.0000$ \\
Pseudo $\mathrm{R}^{2}=0.0690$ & & & \\
\hline
\end{tabular}

Challenges and Opportunities of Microfinance Service Provision

To identify challenges and opportunities of microfinance service provision in the district, necessary data have been gathered through focus group discussion and key informants' interview. During key informants' interview with experts from OMFI sub branch office of the district and local administrative level, major issues mentioned were analyzed in qualitative approach and they are discussed in order of importance as follows.

Major challenges

Low loan recovery performance: Despite loan repayment period for clients of OMFI was one year, due to different reasons, loan recovery time extends to longer time than the allowed period of time. The information from the district OMF sub branch office showed that in some rural kebeles of the district, unpaid loan in arrears have been challenging the outreach and effectiveness of the institution in the district. Since the loan provision is based on group-based collateral, the loan default problem of a person in a group restricts the other members' subsequent loan term, even they had paid their part. In some rural villages, there is default problem and that discouraged farmers for saving participation and credit 
use, as credit use of next round depends on repayment performance of the previous credit.

Low saving mobilization: Low saving habit of clients in OMFI influenced the performance of the institution; despite saving is one of major services offered. Even though the saving habit of clients being improved in the district, still it is low enough to cover the increasing need for credit in the district. Due to this challenge, the institution faced fund shortage in service provision to meet the increasing credit demand in the district. Unbalance between fund from different sources; loan recovery and saving mobilization, with increasing credit demand created fund shortage constraint which sometimes result in lag of loan disbursement time for clients.

Lack of office facilities: It is clear that availability of office equipment like computer, internet service, stationery, vehicles and other materials are necessary for effective and efficient provision of different financial services. However, the report from focus group discussion and key informant interviews with experts in the institution explained the lack of these facilities in OMFI of the district affected microfinance service provision in the district. This has been challenging service provision and limited the capacity of the institution in making the service provision via using modernized system.

Lack of awareness on services: The other challenge was low awareness of some households about the microfinance services in the district. This can be manifested through some mistaken understandings of households about the service of Omo microfinance institution. Comparing saving interest rate with interest rate of credit, comparing and evaluating OMFI service provision with bank services in the district and being unsatisfied and weak loan repayment of some clients by reasoning risks associated with crop failure, animal dying, market problem for agricultural products, etc. In addition, some clients were seeing the institution as solely owned by government and wrong expectation of loan forgiveness during default was some of manifestations of awareness problem.

Lack of coordination with other government sectors: weak loan repayment performance in some kebeles made the institution focus on loan recovery operations by restricting disbursing further loan in those kebeles which were with lower repayment performance. This was because, to reduce disturbance of unpaid loan expansion on credit service environment among rural households. But, in some cases government officials' interference in the service provision of the OMFI for political purpose led to unplanned loan disbursement in some kebeles which were in loan arrears. This condition sometimes made the institution to provide services through troubling between loan disbursement and loan recovery mechanism.

Lack of trained human resource: Lack of trained persons in financial service provision, coupled with staff turnover in the district challenged the institution to increase its outreach and become effective in the service provision in the district. This challenged the Omo microfinance institution in attaining its effective financial inclusion objectives and higher clients' satisfaction.

\section{Opportunities}

The data gathered during focus group discussion and key informants' interview with experts from OMFI sub branch office of the district showed that, despite the above challenges, there were some prevailing opportunities for sustaining the microfinance service provision in the district. The first one is, increasing need for credit in the district. According to the report from district sub branch office, the loan disbursement increased from 3,080,400 to 20,479,615 birr from year $2013 / 14$ to $2016 / 17$. Related with this credit increment, saving mobilization also increased from $2,265,182$ to $13,338,820$ Birr with in these years, despite the fact that it was much lower to cover credit need in the district.

The second one is, youths' job creation and food security strategy by government which is functioned through OMFI in collaboration with other sectors provided additional fund for the institution and helping in expanding its outreach and being playing vital role in improving saving mobilization in the district. Due to this strategy, the institution was getting additional fund source and different youths were participating in saving and borrowing service in OMFI. Since the institution was facing fund shortage, this additional source of fund would help in expanding the services further in sustainable manner if it is managed well. Moreover, these youths' participation in saving and credit participation plays vital role in further promotion of the services of the institution and improving the saving mobilization in the district.

The other opportunity is, the district being potential for cash crops like coffee and fruits. Some of farm households earn better income from sale of farm products in a production season, despite price fluctuations. If the institution attracts those households with better incentives and satisfactory services, the saving habit of farm households would increase and this saving might provide loanable capital base for the institution and then to other credit needy farmers. Since the OMFI is the only microfinance institution working in the district, this is better opportunity to cover the growing credit need in the district and to sustain financial viability in a good manner.

\section{Conclusion}

To improve agricultural productivity and poverty reduction, a powerful tool is provision of microfinance services to the poor in a sustainable way. There are various microfinance institutions which are established to serve poor and lowincome individuals via playing a vital role in terms of credit service and saving mobilization. OMFI was established in SNNPRS as channel through which low income rural people can pass to build their savings which improve credit schemes and financial accessibility. However, farmers' participation in the service is low and it is affected by different household characteristics and institution related factors. 
Mobilizing informal savings into formal institutions would expand the loanable capital base for OMFI as saving is main source of fund for the institution and improve resource allocation in the economy at large. However, there was low saving mobilization in the district, mainly, due to low saving interest rate and inconveniences in withdrawal procedure which also resulted in shortage of loanable funds for the institution for further service outreach in the district. Education level, land size, farm income, household expenditure, distance from service provision center, and perception on interest rate were significant factors affected households' saving in micro finance institutions.

Low loan recovery performance, low saving mobilization, lack of office facilities, lack of clients' awareness on services, and lack of coordination with other government sectors were major challenges in service provision; however, increasing need for credit and youths' job creation and food security strategy by government would help in promoting saving mobilizations and increase outreach and sustain microfinance service provision in the district. The findings showed need to take immediate actions on significant factors affecting saving and improving the saving mobilization to sustain effective service provision and attain poverty alleviation objective.

\section{Recommendations}

Most of households who owned saving account in the microfinance institution were credit users and their motive for saving was mainly credit use. If the institution has to increase its loanable capital base and improve saving mobilization in the district, it would be necessary to promote voluntary saving for both credit seekers and those who do not. Thus, the current low saving level calls for giving focus on policies to improve the existing saving mobilization. Therefore, the institution and concerned government bodies should play role regarding improving saving culture of households through financial literacy, modernization of working procedures in saving service provision, and reviewing the saving interest rate as some of the major issues.

Distance from residence of households to OMFI service provision showed negative relation with households' saving. Therefore, establishing new service provision sub centers and strengthening the capacity of the existing structure of the institution coupled with easy and modernized working procedures to reduce unnecessary shuttling of residents from distant kebeles should get attention to increase participation of the households.

Being male headed household and education level showed positive relation to households saving; as it related to have better information and easily understanding of working procedures for saving services. Therefore, OMFI with local government bodies has to find promotion mechanism and developing and using clear and easy instruments regarding saving account type and amount to increase its outreach and uneducated and female headed households can better participate and benefit from the saving service.

\section{References}

[1] FAO. 2015. Statistical pocketbook2015. Food and Agriculture Organization. Rome.

[2] Aminu S. and Samuel A. 2015. Microfinance impact on agricultural production in developing countries-study of the Pru district in Ghana. International Journal of Academic Research and Reflection Vol. 3, No. 3, 2015.

[3] Obo D. 2009. Microfinance in Ethiopia. Institute of Social Studies.

[4] Dereje K., Yenenesh T., Sisay B. and Jemal Y. 2013. Determinants of women's participation in microfinance services: empirical evidence from Rural Dire Dawa, Ethiopia. African Journal of Agricultural Economics and Rural Development Vol. 1 1, pp. 001-007, September, 2013.

[5] Ebisa D., Getachew N. and Fikadu M. 2013. Filling the breach: Microfinance. Journal of Business, Economics and Management. 1 (1): 10-17.

[6] Asfaw T. and Jema H. 2013. Impact of Microfinance on The Livelihood of Smallholders Farmers: The Case of Oromia Credit and Saving Share Company, Grawa Branch, East Hararghe Zone, Oromia National Regional State, Ethiopia (Doctoral dissertation, Haramaya University).

[7] Mujeri, M. K., 2015. Improving access of the poor to financial services. General Economics Division of the Planning Commission, Bangladesh.

[8] Tony S. Getaneh G. and Anne F. 2014. Overview of Practical Challenges in Local Saving Mobilization by Ethiopian Microfinance Institutions. The Association of Ethiopian Microfinance Institutions (AEMFI), Oct 22-24, 2014 Hawassa, Ethiopia.

[9] CIMMYT. 2015. Financial products for farmers and service providers report Ethiopia.

[10] Gimbo District sub branch Office of Omo Micro Finance Institution (GDOMFI). 2018. Annual report on Saving and loan disbursement, accessed 5 March 2018.

[11] Muluken A. and Mesfin L. 2014. Factors Affecting the Performance of Microfinance Institutions: The Case of Hawassa City. JBAS. Vol. 6 (1). 2014.

[12] Tsega H. and Yemane M., 2014. Determinants of household saving in Ethiopia: a case of North gondar zone, Amhara regional state. International Journal of Development and Economic Sustainability. Vol. 2, No. 4, pp. 37-49, October 2014.

[13] Gimbo District Office of Agriculture and Rural Development (GDOARD). 2018. Report on socio economic profile and background information of the district, accessed 19 March 2018 .

[14] Wolday A. 2000. Review of Microfinance Industry in Ethiopia: Regulatory Frameworks and Performance. The Association of Ethiopian Microfinance Institutions (AEMFI) Occasional Paper No. 2, August, 2000. Addis Ababa, Ethiopia

[15] Addisu A. 2011. Cash Saving and Livelihood Diversification Practice Among Better Off Rural Households in Case of Shashemene District of Oromia Regional State, Ethiopia. 
[16] Yamane T. 1967. Statistics, An Introductory Analysis, 2nd edition. New York.

[17] Maddala, G. S. 1992. Introduction to Econometrics. 2ndEdition. Macmillan Publishing Company, New York, USA

[18] Aron H., Nigus A. and Getnet B. 2013. Assessment of Saving Culture among Households in Ethiopia. Report on Mengistu K., Mengistu U., Nigussie D., Endrias G., Mohammadamin H., Temesgen K., \& Yemisrach G.(eds.), 2013. Proceedings of the National Conference on 'Loan and Saving: The Role in Ethiopian Socioeconomic Development', 15-16 February 2013, Haramaya, Ethiopia.

[19] Alemu T. 2015. Rural Households Saving Behavior: The Case of Wonchi District, Southwest Shewa Zone, Oromia Regional State, Ethiopia. Thesis submitted to Haramaya University. August 2015.

[20] Girma T., Belay K., Bezabih E. and Jemma H. 2014. Saving Patterns of Rural Households in East Hararghe Zone of
Oromia Regional State, Ethiopia. Journal of Development and Agricultural Economics. 6 (4): 177-183.

[21] Parker, J. 2010. Theories of consumption and saving (Economics 314 coursebook)

[22] Birhanu M. 2015. Factors affecting rural households Savings: The case Of Gedeb Hasasa District, West Arsi Zone, Oromia Regional State, Ethiopia. Thesis Submitted to Haramaya University, May 2015

[23] Chemonics International. 2007. Improving access to financial services in rural Uganda: Rural SPEED final report. Washington DC, Chemonics.

[24] Aflonia N. M. 2011. Households' Saving Decisions in Kenya. A Thesis Submitted in Partial Fulfilment of The Requirements for the Award of the Degree of Doctor of Philosophy in The School of Economics of Kenyatta University. November, 2011. 